\title{
Prevalensi Kanker Serviks Berdasarkan Paritas di RSUP. Dr. M. Djamil Padang Periode Januari 2011- Desember 2012
}

\author{
Septia Haryani ${ }^{1}$, Defrin $^{2}$, Yenita $^{3}$
}

\begin{abstract}
Abstrak
Kanker serviks menempati urutan pertama penyebab kematian akibat kanker pada wanita usia reproduktif di negara berkembang. Jumlah paritas di Sumatera Barat masih cukup tinggi, paritas merupakan salah satu faktor risiko terjadinya kanker serviks yang berhubungan dengan hormon dan trauma saat persalinan. Tujuan penelitian ini adalah mengetahui prevalensi kanker serviks berdasarkan jumlah paritas di RSUP. DR. M. Djamil Padang. Penelitian ini merupakan penelitian deskriptif observasional. Data sekunder diambil dari rekam medik pasien kanker serviks di RSUP.Dr. M. Djamil Padang periode Januari 2011- Desember 2012. Penelitian ini dilakukan dari Oktober 2013 - Juni 2014. Pada penelitian ini didapatkan 63 kasus kanker serviks. Distribusi kanker serviks berdasarkan umur terbanyak pada kelompok umur $>50$ tahun sebanyak 27 kasus $(42,9 \%)$, berdasarkan jenis pembayaran pasien kanker serviks banyak memakai jamkesmas sebanyak 21 kasus $(38,1 \%)$, jenis histopatologi terbanyak ditemukan pada jenis karsinoma sel skuamosa sebanyak 46 kasus (73\%) dan jumlah paritas yang terbanyak pada kelompok paritas 3-5 kali sebanyak 40 kasus $(63,5 \%)$. Umur dan paritas tidak ada hubungannya dengan jenis kanker serviks.Paritas bukan merupakan faktor risiko terjadinya kanker serviks.
\end{abstract}

Kata kunci: kanker serviks, paritas, histopatologi

\begin{abstract}
The cervical cancer is the first rank cause of cancer death in women of reproductive age in developing countries. The number of parity in West Sumatera is still high, parity is one of the risk factors for cervical cancer relating to hormone and birth trauma. The objective of this study was to identify the prevalence of cervical cancer based on parity in Dr. M. Djamil Hospital Padang. This research was descriptive observational study. Secondary data was taken from medical record of cervical cancer patients in Dr. M.Djamil Hospital Padang from January 2011 until December 2012. The study was held from October 2013 until June 2014. The research found 63 cases of cervival cancer. Distribution cervical cancer by the age of majority in the age group $>50$ years old were 27 cases (42,9\%), based on kind of payment is mostly used jamkesmas were 21 cases $(38,1 \%)$, based on histopathology of majority on squamous cell carcinoma is 46 cases (73\%) and based on the highest number of parity is the parity group 3-5 were 40 cases (63,5\%). People's age and parity are not related to the type of cervical cancer. Parity is not a risk factor of having cervical cancer.
\end{abstract}

Keywords: cervical cancer, parity, histopathology

Affiliasi penulis: 1. Prodi Profesi Dokter FK UNAND (Fakultas Kedokteran Universitas Andalas Padang 2. Bagian Obstetri Ginekologi FK UNAND, 3.Bagian Patologi Anatomi FK UNAND

Korespondensi: Septia Haryani,

Email:septiaharyani812@yahoo.com, Telp: +62813-6304-6474

\section{PENDAHULUAN}

Kanker serviks merupakan tumor ganas primer yang berasal dari kanalis servikalis dan atau porsio. Kanker ini akan mengenai epitel serviks, dimana sel epitel akan mengalami penggandaan dan berubah 
secara patologi anatomi. Sifat sel yang ganas dapat mengalami penyebaran ke organ - organ lain melalui jalur limfe dan vaskular.,

Kanker serviks merupakan penyakit kanker nomor dua terbanyak yang diderita wanita di dunia, yaitu sekitar 500.000 kasus baru dan kematian 250.000 setiap tahun. Di negara berkembang, kanker serviks masih menempati urutan pertama sebagai penyebab kematian akibat kanker pada wanita usia produktif. Hampir $80 \%$ kasus kanker serviks berada di negara berkembang. Menurut data Organisasi Kesehatan Dunia (WHO) setiap tahun jumlah penderita kanker di dunia bertambah 6,25 juta orang atau setiap 11 menit ada satu penduduk meninggal dunia karena kanker dan setiap 3 menit ada satu penderita kanker baru. ${ }^{3,4}$

Kanker serviks merupakan keganasan ketiga tersering pada traktus genitalia wanita di Amerika setelah kanker endometrium dan ovarium. Selama tahun 1993 diperkirakan terdapat sekitar 13500 kasus baru kanker serviks invasif. ${ }^{5}$

Berdasarkan data pasien rawat inap di rumah sakit seluruh Indonesia sejak tahun 2004 hingga tahun 2008 posisi sepuluh besar utama tumor ganas atau kanker tidak terlalu banyak berubah. Kanker serviks menempati urutan kedua setelah kanker payudara kemudian disusul tumor ganas hati dan saluran empedu intrahepatik. ${ }^{6}$

Menurut Yayasan Kanker Indonesia (YKI) pada tahun 2007, saat ini penyakit kanker serviks menyebabkan korban meninggal sedikitnya 200.000 wanita per tahun atau diperkirakan setiap harinya terjadi 41 kasus baru kanker serviks dan 20 perempuan meninggal karena penyakit tersebut. Kanker terbanyak diderita wanita didapatkan dari 31 RS DKI Jakarta adalah kanker payudara (32\%) disusul kanker serviks (21.5\%) dan kanker ovarium. ${ }^{6}$

Kejadian kanker serviks yang terdeteksi di Laboratorium Patologi Anatomi Fakultas Kedokteran Universitas Andalas (FKUA) Padang pada tahun 2005 didapatkan adanya 188 kasus (47,48\%) karsinoma serviks uteri dari 393 kasus keganasan ginekologi dan kanker serviks menempati peringkat pertama. Data dari RSUP DR. M. Djamil Padang penderita kanker serviks pada tahun 2009 sebanyak 37 kasus dan mengalami peningkatan pada tahun 2010 dan 2011 sebanyak 58 kasus dan tahun 2012 sebanyak 42 kasus. $^{7}$

Kanker serviks disebabkan oleh adanya infeksi Human Papiloma Virus (HPV). HPV merupakan suatu virus DNA yang digolongkan berdasarkan sekuens DNA nya dan di bagi menjadi risiko onkogenik tinggi dan rendah. HPV onkogenik risiko tinggi saat ini menjadi satu- satunya faktor yang sangat penting pada proses keganasan serviks. Dari segi patologi serviks, HPV tipe 16 dan 18 adalah yang paling penting dimana HPV 16 bertanggung jawab atas $60 \%$ kasus kanker serviks sedangkan HPV 18 mencakup $10 \%$ kasus. Beberapa tipe lainnya masing-masing berkontribusi pada kurang dari 5\% kasus. Beberapa faktor lain yang berpengaruh yaitu perilaku seksual, seperti umur pertama kali melakukan hubungan seksual, aktivitas seksual yang sering berganti-ganti pasangan, jumlah paritas, sosial ekonomi yang rendah berkaitan dengan pendidikan yang rendah serta kebiasaan merokok. ${ }^{8,9}$

Peningkatan kasus karsinom serviks setiap tahun dapat diperburuk dengan bervariasinya faktorfaktor risiko setiap daerah. Sebagaimana kanker pada umumnya, kanker serviks menimbulkan masalahmasalah berupa morbiditas, mortalitas, finansial/ekonomi, lingkungan dan pemerintah. Morbiditas dan mortalitas yang semakin meningkat dipengaruhi seberapa besar keinginan pasien untuk memeriksakan diri secara dini. Hal ini dikarenakan perkembangan kanker serviks yang berlangsung sangat lamban. Sebagian besar penderita datang ke tempat pelayanan kesehatan sudah dalam stadium lanjut, sehingga pengobatan terhadap kanker serviks memberikan hasil yang tidak memuaskan. ${ }^{2,10}$

Paritas merupakan salah satu faktor ekstrinsik yang berhubungan erat dengan kejadian kanker serviks apalagi bila jarak persalinan terlampau dekat. Kategori partus belum ada keseragaman, namun di duga risiko untuk terjadinya kanker serviks akan meningkat 3 - 5 kali lebih besar pada wanita yang sering partus. Pengaruh hormon selama kehamilan menjadi lebih mudah untuk berkembangnya sel kanker, hal ini dihubungkan dengan proses metaplasia sel serviks uteri, rendahnya daya imun perempuan 
saat hamil serta trauma yang disebabkan oleh proses saat melahirkan. ${ }^{1,11}$

Indonesia yang memiliki penduduk 240 juta dengan $70 \%$ penduduknya hidup di pedesaan serta proporsi wanita setengah dari penduduk dengan dua per tiganya berada pada usia reproduksi. Bervariasinya ekonomi penduduk indonesia berpengaruh pada keinginan memiliki anak pada sebuah keluarga. Paparan media massa dan pendidikan berpengaruh pada keinginan seorang wanita memiliki anak. Rendahnya pengetahuan lbu karena paparan informasi yang kurang serta rendahnya kemampuan ekonomi yang membatasi pada akses pelayanan kesehatan membuat seorang ibu masih memiliki banyak anak. ${ }^{11}$

Pada perempuan dengan umur pertama haid yang masih muda, dan perkawinan dibawah umur, membuat panjang rentang usia reproduksi perempuandan berdampak pada banyaknya anak yang dilahirkan. Secara nasional, dapat dilihat ada 8,4\% perempuan 10-59 tahun melahirkan 5-6 anak, serta $3,4 \%$ melahirkan anak lebih dari 7. Provinsi dengan kelompok perempuan mempunyai anak lebih dari 7 tertinggi adalah Papua Barat (7,5\%) dan terendah di Yogyakarta(0,5\%). Konsisten dengan indikator lainnya, kelompok perempuan yang tinggal di perdesaan, tidak sekolah, petani, nelayan, buruh, dan status ekonomi terendah cenderung mempunyai anak lebih dari 7 lebih tinggi dari kelompok lainnya. ${ }^{12}$

Berdasarkan jumlah anak yang dilahirkan dari 33 provinsi per 1000 perempuan di Indonesia, jumlah kelahiran di Sumatera Barat masih cukup tinggi jika dibandingkan dengan provinsi di sumatera lainnya. Sumatera Barat menempati urutan ke 2 pada kelompok paritas $3-4$ kali $(35,5 \%)$ setelah Sumatera Utara $(36,1 \%)$. Kelompok paritas 5- 6 menempati urutan ke 3 (14,9\%) setelah NTT (20,4\%) dan Sulawesi Barat $(15,8 \%)$ dan paritas $>7$ menempati urutan ke 7 sebanyak (5,6\%). ${ }^{12}$

Beberapa literatur yang didapatkan bahwa telah banyak penelitian tentang kanker serviks di Indonesia, akan tetapi di Sumatera Barat masih jarang ditemukan. Menyadari kasus kanker serviks yang semakin meningkat setiap tahunnya dan jumlah paritas yang masih cukup tinggi di Sumatera Barat, maka atas dasar itu, perlu dilakukan penelititan di RSUP. dr. M. Djamil Padang untuk mengetahui prevalensi kanker serviks berdasarkan jumlah paritas selama dua tahun (1 Januari 2011- 31 Desember 2012).

\section{METODE}

Jenis penelitian ini merupakan penelitian deskriptif observasional dengan mengunakan catatan rekam medis penderita kanker serviks di RSUP. DR. M. Djamil Padang untuk melihat distribusi frekuensi kanker serviks berdasarkan jumlah paritas.

\section{HASIL}

Adapun karakteristik dari sampel penelitian adalah sebagai berikut:

Tabel 1. Karakteristik penderita kanker serviks berdasarkan umur

\begin{tabular}{lcc}
\hline \multicolumn{1}{c}{ Karakteristik } & $\mathbf{f}$ & $\%$ \\
\hline Kelompok umur (tahun) & 2 & 3,2 \\
$20-30$ & 9 & 14,3 \\
$>30-40$ & 25 & 39,7 \\
$>40-50$ & 27 & 42,9 \\
$>50$ & 63 & 100 \\
\hline$\quad$ Jumlah & 18 & 28,6 \\
\hline Jenis pembayaran & 8 & 12,7 \\
Umum & 21 & 38,1 \\
Askes & 11 & 17,5 \\
Jamkesmas & 2 & 3,2 \\
Jamkesda & 63 & 100 \\
$\quad$ Bazda kota Padang & 34 & 54 \\
\hline Jumlah & & \\
\hline Tempat tinggal & & \\
$\quad$ Kota Padang dan & sekitarnya & 100 \\
$\quad$ Luar kota padang & 29 & \\
\hline$\quad$ Jumlah & 63 &
\end{tabular}

Berdasarkan Tabel 1, didapatkan sampel terbanyak pada kelompok umur $>50$ tahun sebanyak 27 orang $(42,9 \%)$ dan terendah pada kelompok umur 20- 30 tahun sebanyak 2 orang (3,2\%). Berdasarkan jenis pembayaran pasien kanker serviks banyak memakai jamkesmas sebanyak 21 orang $(38,1 \%)$. Tempat tinggal penderita kanker serviks didapatkan di 
kota Padang dan sekitarnya sebanyak 34 orang (54\%) dan di luar kota Padang sebanyak 29 orang (46\%).

Tabel 2. Distribusi penderita kanker serviks berdasarkan jenis histologi

\begin{tabular}{lcc}
\hline Diagnosis & $\mathbf{f}$ & $\%$ \\
\hline Karsinoma sel skuamosa & 46 & 73 \\
Adenokarsinoma & 15 & 23,8 \\
Karsinoma adenosquamosa & 2 & 3,2 \\
\hline Jumlah & 63 & 100 \\
\hline
\end{tabular}

Berdasarkan Tabel 2 didapatkan data bahwa jenis histologik kanker serviks terbanyak adalah karsinoma sel skuamosa sebanyak 46 orang (73\%) dan paling jarang ditemukan jenis karsinoma adenosquamosa (3,2\%). Sedangkan untuk jenis sarkoma, melanoma, karsinoid dan limfoma tidak ditemukan pada penelitian ini.

Tabel 3. Distribusi sampel berdasarkan jumlah paritas

\begin{tabular}{ccc}
\hline Jumlah Paritas & $\mathbf{f}$ & $\%$ \\
\hline $0-2$ & 18 & 28,6 \\
$3-5$ & 40 & 63,5 \\
$>5$ & 5 & 7,9 \\
\hline Jumlah & 63 & 100 \\
\hline
\end{tabular}

Pada Tabel 3 diperoleh sampel terbanyak pada kelompok paritas 3-5 kali sebanyak 40 orang $(63,5 \%)$.

Tabel 4. Distribusi kanker serviks berdasarkan paritas dan jenis histopatologi

\begin{tabular}{lcccc}
\hline \multicolumn{1}{c}{$\begin{array}{c}\text { Jenis } \\
\text { histopatologi }\end{array}$} & \multicolumn{3}{c}{ Paritas } & Jumlah \\
\cline { 2 - 4 } & $\mathbf{0 - 2}$ & $\mathbf{3 - 5}$ & $\mathbf{> 5}$ & \\
\hline $\begin{array}{l}\text { Karsinoma sel } \\
\text { skuamosa }\end{array}$ & 13 & 28 & 5 & 46 \\
$\begin{array}{l}\text { Adenokarsinoma } \\
\text { Karsinoma }\end{array}$ & 4 & 11 & 0 & 15 \\
\begin{tabular}{l} 
adenoskuamosa \\
\multicolumn{1}{c}{ Jumlah }
\end{tabular} & 1 & 1 & 0 & 2 \\
\hline
\end{tabular}

Berdasarkan Tabel 4 ditemukan kasus terbanyak pada kelompok paritas 3-5 sebanyak 40 orang. Jenis histopatologi yang sering ditemukan adalah jenis karsinoma sel skuamosa.

\section{PEMBAHASAN}

Penelitian yang dilakukan di Laboratorium Patologi Anatomi dan Rekam Medis di RSUP. DR. M. Djamil Padang selama 2 tahun periode Januari 2011 sampai Desember 2012 didapatkan penderita kanker serviks sebanyak 63 orang.

Menurut literature, umur merupakan salah satu faktor risiko yang dianggap mempengaruhi prognosis penderita dan mempengaruhi kematangan sistem imun. Pada umur muda hingga dewasa kemampuan imun akan mencapai puncaknya dan lambat laun akan menurun terutama pada usia agak lanjut. Insiden kanker serviks yang masih tinggi pada umur lebih tua menunjukkan masih kurangnya keinginan dan perhatian masyarakat untuk melakukan skrining kanker serviks. $^{14}$

Kanker serviks terbanyak ditemukan pada kelompok umur >50 tahun. Hal ini sejalan dengan penelitian yang dilakukan oleh Fulviona pada tahun 2012 yang menemukan penderita kanker serviks terbanyak pada kelompok umur 51-60 tahun. ${ }^{14}$ Thamrin tahun (2011) juga menemukan penderita kanker serviks terbanyak pada umur 51-55 tahun. ${ }^{15}$

Proporsi terkecil penderita kanker serviks didapatkan pada kelompok umur 20-30 tahun sebanyak 2 orang (3,2\%). Hal ini mungkin disebabkan karena masih jarang terpapar oleh infeksi virus HPV yang dapat ditularkan secara hubungan seksual serta rendahnya faktor risiko lain seperti jumlah paritas, pola hubungan seksual dan riwayat berganti pasangan. Kejadian kanker serviks dapat ditemukan pada umur lebih muda kemungkinan bisa disebabkan oleh tipe HPV yang menginfeksi epitel serviks, faktor host serta faktor lain seperti hubungan seksual pertama yang dilakukan pada usia dini yaitu <20 tahun dan hamil di usia muda sehingga rentan terpapar oleh virus HPV. ${ }^{2,8}$

Jenis pembayaran yang sering digunakan masyarakat adalah Jamkesmas sebesar 38,1\%. Hal ini menunjukkan bahwa sebagian besar penderita kanker serviks adalah masyarakat yang kurang mampu. Tingginya kasus kanker serviks pada masyarakat yang kurang mampu juga berpengaruh terhadap kebersihan, pengetahuan dan sikap untuk melakukan skrining deteksi dini kanker serviks. ${ }^{9}$ 
Berdasarkan alamat, penderita kanker serviks hampir tidak jauh berbeda antara yang berdomisili di kota Padang dan sekitar dengan di luar kota Padang. Penderita kanker serviks di Kota padang sedikit lebih banyak dibandingkan di luar kota padang. Hal ini kemungkinan disebabkan tidak seluruh masyarakat kota Padang mengetahui dan memahami kesadaran mengenai faktor risiko dan keinginan melakukan pemeriksaan deteksi dini kanker serviks. Penderita kanker serviks di luar kota Padang yang lebih sedikit ditemukan bukan berarti kasus kanker serviks rendah, hal ini kemungkinan bisa disebabkan salah satunya pelayanan kesehatan yang kurang terjangkau sehingga membuat penderita kanker serviks enggan untuk berobat.

Jenis histologi kanker serviks terbanyak adalah karsinoma sel skuamosa sebanyak $73 \%$.Paritas 3-5 tertinggi ditemukan pada karsinoma sel skuamosa. Berdasarkan literatur insiden tertinggi kanker serviks memiliki jenis histologi karsinoma skuamosa sebesar 90\%. Jenis dari histologi kanker serviks berpengaruh pada prognosis penyakit. Karsinoma jenis skuamosa memiliki prognosis relatif baik jika dibandingkan dengan jenis adenokarsinoma dan karsinoma adenoskuamosa.

Paritas pasien kanker serviks didapatkan tertinggi pada kelompok 3-5 kali sebanyak 40 orang (63,5\%). Fulviona pada tahun 2012 menemukan penderita kanker serviks terbanyak memiliki paritas $\geq 3$ kali. $^{14}$ Surbakti pada tahun 2004 juga menemukan bahwa penderita kanker serviks mayoritas memiliki paritas $\geq 3 .{ }^{16}$ Pada tahun 2005 Sasmita menemukan distribusi terbanyak penderita kanker serviks pada paritas $\geq 5$. Multi paritas merupakan salah satu faktor risiko terjadinya kanker serviks. ${ }^{7}$ Saat ini jumlah paritas yang mempengaruhi kejadian kanker serviks berubah pada paritas $\geq 3$ hal ini mungkin disebabkan paritas bukan faktor risiko tunggal kanker serviks. ${ }^{8}$

Pada penelititan ini keadaan kanker serviks ditemukan juga pada wanita dengan paritas 0 dan wanita dengan paritas tinggi $>5$ jarang mengalami kanker serviks.Hal ini menunjukan paritas bukan merupakan faktor risiko terjadinya kanker serviks. Keterbatasan pada penelitian ini, pada data rekam medis petugas kurang mencantumkan identitas pasien secaralengkap sehingga peneliti kesulitan dalam mencari faktor risiko lain yang dapat menyebabkan kanker serviks.

Pencegahan terjadinya kanker serviks maka perlu adanya pemberian informasi kepada masyarakat tentang faktor risiko kanker serviks terutama untuk masyarakat yang bertempat tinggaljauh dari pusat kota dan pelayanan kesehatan. Informasi ini dapat diberikan dalam bentuk penyuluhan, leaflet, brosur ataupun melalui media lain yang mudah diakses oleh masyarakat umum. Masyarakat lebih diharapkan untuk melakukan skrining kanker serviks terutama pada kelompok risiko tinggi agar insiden kanker serviks dapat berkurang.

\section{KESIMPULAN}

Didapatkan frekuensi kanker serviks periode Januari 2011- Desember 2012 di RSUP. DR. M. Djamil Padang sebanyak 63 orang.

Pada pasien kanker serviks didapatkan kelompok tertinggi pada paritas 3-5 kali sebanyak 40 orang $(63,5 \%)$.

\section{UCAPAN TERIMA KASIH}

Ucapan terima kasih yang sebesar- besarnya kepada semua pihak atas bimbingan dan arahannya dalam penelitian ini.

\section{DAFTAR PUSTAKA}

1. Mardjikoen P. Tumor ganas alat genital. Dalam: Hanifa W, Abdul Bari S, Sumapraja S, editor (penyunting). Ilmu kandungan. Jakarta: Yayasan Bina pustaka Sarwono Prawirohardjo; 2008. hlm. 380-8.

2. Edianto D. Kanker serviks uteri. Dalam: Saifuddin, Abdul Bari, Aziz MF, editor (penyunting). Buku acuan nasional onkologi ginekologi. Jakarta: Yayasan Bina Pustaka Sarwono Prawirohardjo; 2006. hlm. 442-54.

3. Aziz MF. Onkologi Ginekologi. Jakarta: Yayasan Bina Pustaka Sarwono Prawirohardjo; 2006. hlm. 443-55. 
4. Diananda R. Mengenal seluk beluk kanker. Yogyakarta: Katahati; 2009.

5. Gant N, Cunningham G. Dasar -dasar ginekologi dan obstetri (terjemahan). Jakarta: EGC; 2010.

6. Departemen Kesehatan Indonesia. Laporan hasil riset kesehatan dasar (RISKESDAS) 2007. Jakarta: Depkes RI; 2008.

7. Sasmita N. Frekuensi karsinoma serviks di laboratorium patologi anatomi Fakultas Kedokteran Universitas Andalas periode januari 2001 desember 2004 (skripsi). Padang: Fakultas Kedokteran Universitas Andalas; 2005.

8. Kumar. Pathologic Basis of Disease. Edisi ke-8. Philadelphia: Saunders Elsevier; 2009.

9. Andrijono. Vaksinasi HPV merupakan pencegahan primer kanker serviks. Majalah Kedokteran Indonesia. 2007:153-5.

10. Manuaba, Ida Gede Bagus. Gawat darurat obstetri dan obstetri ginekologi sosial untukprofesi bidan. Jakarta: EGC; 2008.

11. Departemen Kesehatan Republik Indonesia.
Pedoman pengendalian faktor risiko penyakit kanker. Ditjen PP \& PL Depkes RI: Jakarta; 2007.

12. Departemen Kesehatan Indonesia. Laporan hasil riset kesehatan dasar (RISKESDAS) 2010: Jakarta: Depkes RI; 2011.

13. Robbin SL, Kumar V, Cotran R, editor (penyunting). Buku ajar patologi robbin (terjemahan). Edisi ke-7. Jakarta: EGC; 2007.

14. Fulviona A. Hubungan paritas dengan kejadian kanker serviks di RSUD. Dr. Pringadi (KTI). Medan: Fakultas Kedokteran Universitas Sumatera Utara; 2012.

15. Thamrin M. Risiko yang berhubungan dengan kanker serviks di RSUP. Dr. Wahidin Sudirohusdo (skripsi). Makasar: Fakultas Kedokteran Universitas Hasanuddin; 2011.

16. Surbakti E. Pendekatan faktor risiko sebagai rancangan alternatif dalam penanggulangan kanker serviks di Rumah Sakit Pringadi Medan (tesis). Medan: Fakultas Kedokteran Univertas Sumatera Utara; 2004. 